\title{
Polymyalgia Rheumatica After Herpes Zoster
}

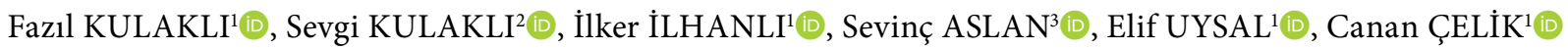 \\ ${ }^{1}$ Department of Physical Medicine and Rehabilitation, Giresun University Prof. Dr. İlhan Özdemir Training and Research Hospital, Giresun, Turkey \\ ${ }^{2}$ Department of Dermatology, Giresun University Prof. Dr. İlhan Özdemir Training and Research Hospital, Giresun, Turkey \\ ${ }^{3}$ Department of Infectious Diseases, Giresun University Prof. Dr. İlhan Özdemir Training and Research Hospital, Giresun, Turkey
}

Polymyalgia rheumatica (PMR) is a systemic disease associated with widespread body pain, in the elderly. ${ }^{1}$ Herpes zoster (HZ) is characterized by painful vesicular rash with dermatomal distribution. ${ }^{2}$ Although it causes many complications, to our knowledge, PMR secondary to $\mathrm{HZ}$ has not been previously reported.

A 64-year-old female patient who was suffering from severe pain in her shoulders and legs for two weeks was admitted to our clinic. Her pain was very intense in the mornings and the Visual Analog Scale (VAS) pain score was 10 . The patient explained that she began to suffer from pain in the right ear and throat with accompanying rash around the ear two weeks ago. She was diagnosed with $\mathrm{HZ}$ by the dermatology department and valaciclovir $500 \mathrm{mg} 3 \times 2$ was started. On the fifth day of treatment, shoulder and leg pain started and peaked on the $10^{\text {th }}$ day. No pathology was found in rheumatologic examination. She stated that one of her three sons had Behçet's disease, the other had familial Mediterranean fever and the third one had acute rheumatic fever. The patient had no history of any chronic systemic disease. Upper extremity movements were normal but painful. There was diffuse swelling and extreme sensitivity with palpation on lower extremities. The movements of lower extremities were also painful. There was no scalp tenderness or headache. The pulses of the temporal arteries were normal. White blood cell (WBC: 19300/(mm³), erythrocyte sedimentation rate (ESR: $93 \mathrm{~mm} / \mathrm{hr}$ ) and $\mathrm{C}$-reactive protein (CRP: $47 \mathrm{mg} / \mathrm{L}$ ) values were elevated in the laboratory tests. She had a consultation with an infectious diseases clinic but no infection focus was found. As a result of all evaluations, the patient was diagnosed with PMR and methylprednisolone $16 \mathrm{mg} /$ day was started. A dramatic clinical response was obtained. A significant decrease was observed in the laboratory parameters by the seventh day (WBC: 10400/ $\mathrm{mm}^{3}$, CRP: $0.60 \mathrm{mg} / \mathrm{L}$, ESR: $52 \mathrm{~mm} / \mathrm{hr}$ ) and the VAS score was 3 .

Although the exact cause of the disease is unknown, some infectious agents such as Mycoplasma pneumoniae, Chlamydia pneumoniae, and Parvovirus B19 may cause PMR. ${ }^{1}$ In addition, the literature includes cases of giant cell arteritis (GCA) and PMR after influenza vaccination. ${ }^{3}$ The relationship between varicella zoster virus (VZV) and GCA remains unclear and the association between VZV and PMR has never been discussed in the literature before. There are few studies that do not

\section{Received: January 27, 2018 Accepted: February 03, 2018 Published online: March 23, 2018}

Correspondence: Fazıl Kulaklı, MD. Giresun Üniversitesi Prof. Dr. İlhan Özdemir Eğitim ve Araştırma Hastanesi, Fiziksel Tıp ve Rehabilitasyon Kliniği, 28200 Giresun, Turkey. Tel: +90 505 - 3121016 e-mail:drfzl46@gmail.com 
support the hypothesis of the GCA development after VZV reactivation. ${ }^{4,5}$ Contrary to these studies, VZV antigen was detected in temporal arteries of patients with GCA in a study. ${ }^{6}$ Another study reported that VZV is a risk factor for the development of GCA. In this study, it was suggested that PMR and GCA were similar diseases and $\mathrm{HZ}$ could also cause PMR, so PMR patients were excluded from the study. ${ }^{7}$ In our case the patient was not diagnosed with GCA. However since PMR and GCA share similar pathophysiologic mechanisms, we also think that $\mathrm{HZ}$ may play a role in the development of PMR as noted in the article by England et al. ${ }^{7}$

\section{Declaration of conflicting interests}

The authors declared no conflicts of interest with respect to the authorship and/or publication of this article.

\section{Funding}

The authors received no financial support for the research and/or authorship of this article.

\section{REFERENCES}

1. Iwata K, Mizuno Y. A case of polymyalgia rheumatica following influenza B infection. Int $\mathrm{J}$ Gen Med 2015;8:345-7.

2. Hussey $\mathrm{H}$, Abdullahi L, Collins J, Muloiwa R, Hussey G, Kagina B. Varicella zoster virus-associated morbidity and mortality in Africa - a systematic review. BMC Infect Dis 2017;17:717.

3. Soriano A, Verrecchia E, Marinaro A, Giovinale M, Fonnesu C, Landolfi R, et al. Giant cell arteritis and polymyalgia rheumatica after influenza vaccination: report of 10 cases and review of the literature. Lupus 2012;21:153-7.

4. Lotan I, Steiner I. Giant cell arteritis following varicella zoster vaccination. J Neurol Sci 2017;375:158-9.

5. Muratore F, Croci S, Tamagnini I, Zerbini A, Bellafiore $\mathrm{S}$, Belloni $\mathrm{L}$, et al. No detection of varicella-zoster virus in temporal arteries of patients with giant cell arteritis. Semin Arthritis Rheum 2017;47:235-40.

6. Gilden D, Nagel M. Varicella Zoster Virus in Temporal Arteries of Patients With Giant Cell Arteritis. J Infect Dis 2015;212 Suppl 1:S37-9.

7. England BR, Mikuls TR, Xie F, Yang S, Chen L, Curtis JR. Herpes Zoster as a Risk Factor for Incident Giant Cell Arteritis. Arthritis Rheumatol 2017;69:2351-2358. 